\title{
The Green Machine ${ }^{1}$
}

\author{
Charles Jacoby, Nanette Holland, and Debbi Berger ${ }^{2}$
}

\section{UF | FLOORIDA IFAS Extension \\ The Institute of Food and Agricultural Sciences (IFAS) is an Equal Opportunity Institution authorized to provide research, educational information and other services only to individuals and institutions that function with non- discrimination with respect to race, creed, color, religion, age, disability, sex, sexual orientation, marital status, national origin, political opinions or affiliations. For more information on obtaining other extension publications, contact your county Cooperative Extension service.}

U.S. Department of Agriculture, Cooperative Extension Service, University of Florida, IFAS, Florida A. \& M. University Cooperative Extension Program, and Boards of County Commissioners Cooperating. Larry Arrington, Dean.

\section{Copyright Information}

This document is copyrighted by the University of Florida, Institute of Food and Agricultural Sciences (UF/IFAS) for the people of the State of Florida. UF/IFAS retains all rights under all conventions, but permits free reproduction by all agents and offices of the Cooperative Extension Service and the people of the State of Florida. Permission is granted to others to use these materials in part or in full for educational purposes, provided that full credit is given to the UF/IFAS, citing the publication, its source, and date of publication.

\footnotetext{
${ }^{1}$ This document is CIR1512, an Activity in an Invasive Species Curriculum (CIR1496), and it is reprinted by permission of the Tampa Bay Estuary Program and The Florida Aquarium. Original EDIS publication date: January, 2007. It was supported by the Tampa Bay Estuary Program, the Florida Aquarium, the Department of Fisheries and Aquatic Sciences of the University of Florida, and the National Sea Grant College Program of the National Oceanic and Atmospheric Administration (NOAA), U.S. Department of Commerce, under NOAA Grant No. NA 16RG-2195. Visit the EDIS Web Site at http://edis.ifas.ufl.edu.

${ }^{2}$ Charles Jacoby, Assistant Professor, Department of Fisheries and Aquatic Sciences, Cooperative Extension Service, Institute of Food and Agricultural Sciences, University of Florida, Gainesville, 32611; Nanette Holland, Public Outreach Coordinator, Tampa Bay Estuary Program, 100 8th Avenue S.E., MS I-1 / NEP, St. Petersburg, FL 33701; Debbi Berger, Vice President of Education, The Florida Aquarium, Inc., 701 Channelside Drive, Tampa, Florida, 33602.
} 
This page was intentionally left blank. 


\section{Invasive Species \\ Series
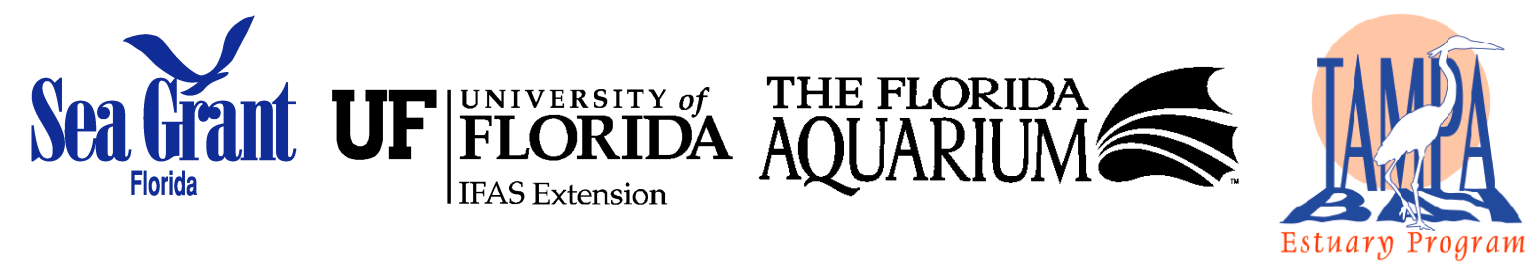 \\ The Green Machine}

\section{Sne ak Pe e K \\ Students will be introduced to Green $\mathcal{T}$ ide, a non-native underwater alga affecting Florida reefs. They will explore two methods to sample coral reefs: quadrat and point transect. Students will calculate the amount of Green $\mathcal{T}$ ide, coral and fish found on a "reef" in the classroom. This activity incorporates math skills and data gathering, recording and analysis.}

Aligned with the following $S$ unshine State Standards and $\mathcal{F C A T}$ Benchmarks for grades $6 \cdot 8:$

SC.D.2.3.2 $\mathcal{A} \mathcal{A} \quad S C . G .2 .3 .4 \quad \mathcal{A} \mathcal{A}$ SC.F.1.3.7 CS SC.H.2.2.1 CS $S C . G .2 .3 .3 \mathrm{CS}$

$\mathcal{A} \mathcal{A}=$ annually assessed

CS = content sampled

\section{Objectives:}

Students will:

- Be able to identify two sampling methods used in reef research.

- Be able to explain which sampling methods most accurately represent the reef as a whole.

- Be able to explain why different methods are appropriate for different studies.

- Be introduced to Green Tide, Caulerpa brachypus, an invasive algae affecting coastal Florida.

\section{Materials:}

- Large open area (open classroom size or larger)

- 10 - 15 whole pieces of construction paper.

- Approximately 60 cup lids or Tupperware lids and 25 - 35 paperclips.

- Two metric tape measures.

- $1 \times 1$ meter quadrat of PVC pipe with ten $10 \mathrm{~cm} \times 10 \mathrm{~cm}$ squares formed by string.

- Calculators.

\section{Background:}

Increasing in numbers, spreading, or occupying space are common characteristics of an invasive species, that is a non-native species that can cause harm. Measuring changes in abundance, the number of organisms in an area, or cover, the space covered by plants or animals, becomes important to scientists that attempt to study effects and impacts of an invasive species. Green Tide on a coral reef provides an example of how scientists accomplish this critical task. 


\section{H ow can coral reef scientists determine how many plants or animals live in an area?}

W orking underwater to determine how many living things are there can be tricky. Sampling is one way to determine how many plants or animals, including coral, are on a reef. Sampling focuses on counting living things in a few small sections of the reef, and the results are used to estimate quantities for the whole reef.

Green Tide, or Caulerpa brachypus, is a non-native alga that is spreading along the East Coast of southern Florida. It smothers and kills corals, forcing fish and invertebrates to find other places for food and shelter. Determining how much $\mathrm{G}$ reen Tide is on reefs represents an important step in understanding and potentially stopping its spread.

\section{What are two common sampling methods?}

Q uadrats are survey grids of a fixed size and shape. In one of the most common forms of sampling, these grids are randomly placed in the study area (not only in the most or least diverse sections). O nce the quadrat is placed on the reef surface, plants and animals within the grid can be counted or the area covered by plants and animals can be estimated (e.g. coral covering more than $50 \%$ of the grid).

Point Transects use a tape measure anchored at a randomly chosen point and stretched to a predetermined length. In this method, the presence of coral, rock, algae or any plant or animal of interest at predetermined intervals (e.g. every $10 \mathrm{~cm}$ ) is recorded.

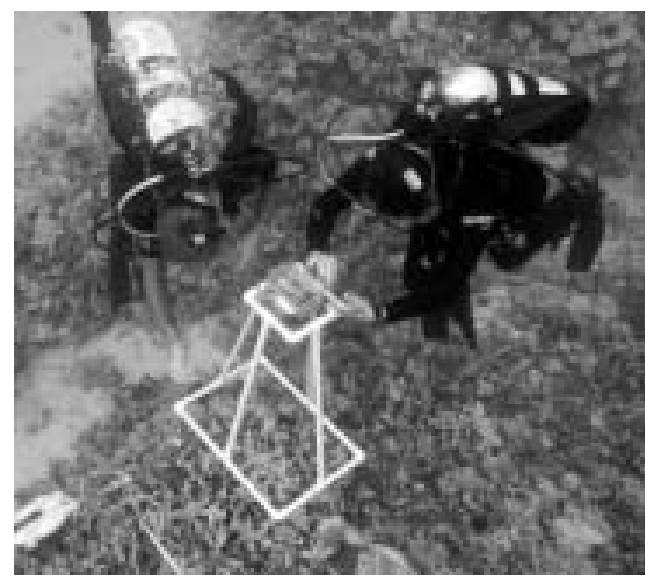

Divers using quadrat equipped with a camera to measure coral cover.

(C ourtesy of U niversity of Hawaii Botany department:

http://www.hawaii.edu/reefalgae/publications/methodsmanual/photoquadratsurvey.htm) 


\section{Procedure:}

1. Before class, place five pieces of construction paper in each of 2-3 patches to represent coral reefs on sand (make the total area of sand and coral to be sampled at least $3 \times 3$ meters). Scatter lids and paper clips around the reefs. The lids represent Green Tide and the paper clips are fish. Do not place paper clips on top of the lids.

2. Count the fish and measure the area covered by coral (construction paper) and Green Tide (lids).

3. Split students into at least three groups. Each group will perform both sampling methods and record their data.

a. For the quadrat method, have students randomly place the quadrat within the area to be sampled. Classify the area under each $10 \mathrm{~cm}$-squared part of the grid as coral, sand or G reen Tide based on whichever covers more than $50 \%$ of the area. Have the students count the number of fish in their quadrat. Repeat this several times. Instruct students to select the random areas by using criteria such as paces in predetermined directions.

b. For the point transect method, place one end of the tape measure randomly on the reef. Stretch the tape measure out to 1.5 meters in any direction. Have students record what is directly under the tape every $10 \mathrm{~cm}$.

6. Use the worksheet to determine the total percentage cover of coral and $\mathrm{G}$ reen Tide and fish density for each method. 


\section{THE GREEN MACHINE WORKSHEET}

NAME

DATE

\section{QUADRAT METHOD}

\begin{tabular}{|l|c|c|c|}
\cline { 2 - 4 } \multicolumn{1}{c|}{} & $\begin{array}{c}\text { TOTAL \# OF } \\
\text { GRIDS IN } \\
\text { QUADRAT }\end{array}$ & $\begin{array}{c}\text { \# OF GRIDS CONTAINING 50\% } \\
\text { OR MORE CORAL OR GREEN } \\
\text { TIDE }\end{array}$ & $\begin{array}{c}\text { \% COVER OF CORAL OR GREEN TIDE } \\
\text { ( OF GRIDS CONTAINING CORAL OR } \\
\text { GREEN TIDE / TOTAL \# OF GRIDS) }\end{array}$ \\
\hline CORAL & & & \\
\hline $\begin{array}{l}\text { GREEN } \\
\text { TIDE }\end{array}$ & & & \\
\hline
\end{tabular}

\begin{tabular}{|c|c|c|c|}
\cline { 2 - 4 } \multicolumn{1}{c|}{} & $\begin{array}{c}\text { TOTAL QUADRAT } \\
\text { AREA }\end{array}$ & $\begin{array}{c}\text { \# OF FISH IN } \\
\text { QUADRAT }\end{array}$ & $\begin{array}{c}\text { FISH DENSITY } \\
\text { (\# OF FISH / TOTAL QUADRAT AREA) }\end{array}$ \\
\hline \multirow{2}{*}{ FISH } & & & \\
\hline
\end{tabular}

\section{POINT TRANSECT METHOD}

\begin{tabular}{|l|c|c|c|}
\cline { 2 - 4 } \multicolumn{1}{c|}{} & $\begin{array}{c}\text { TOTAL \# OF } \\
\text { POINTS SAMPLED }\end{array}$ & $\begin{array}{c}\text { \# OF POINTS DIRECTLY } \\
\text { OVER CORAL OR GREEN } \\
\text { TIDE }\end{array}$ & $\begin{array}{c}\text { \% COVER OF CORAL OR GREEN TIDE } \\
\text { (\# OF POINTS OVER CORAL OR } \\
\text { GREEN TIDE / TOTAL \# OF POINTS) }\end{array}$ \\
\hline CORAL & & & \\
\hline $\begin{array}{l}\text { GREEN } \\
\text { TIDE }\end{array}$ & & & \\
\hline
\end{tabular}

\begin{tabular}{|c|c|c|c|c|c|}
\cline { 2 - 6 } \multicolumn{1}{c|}{} & $\begin{array}{c}\text { TOTAL\# OF } \\
\text { POINTS } \\
\text { SAMPLED }\end{array}$ & $\begin{array}{c}\text { \# OF POINTS } \\
\text { DIRECTLY } \\
\text { OVER FISH }\end{array}$ & $\begin{array}{c}\text { WIDTH } \\
\text { OF } \\
\text { TAPE }\end{array}$ & $\begin{array}{c}\text { TOTAL AREA } \\
\text { SAMPLED (TOTAL \# } \\
\text { OF POINTS X WIDTH } \\
\text { OF TAPE) }\end{array}$ & $\begin{array}{c}\text { FISH DENSITY } \\
\text { (\# OF POINTS DIRECTLY } \\
\text { OVER FISH / TOTAL AREA } \\
\text { SAMPLED) }\end{array}$ \\
\hline FISH & & & & \\
\hline
\end{tabular}




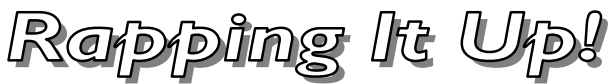

1. W hich method was the hardest to do and why? W hich method was the easiest to do and why?

2. Pick one of the sampling methods and explain why your estimates of fish, coral or Green Tide differ from what is actually on your "classroom reef."

3. If you were a scientist studying $\mathrm{G}$ reen Tide, which method would you use and why?

4. Using what you learned in this experiment, why do you think Green Tide poses a problem for corals and fish? 


\section{Glossary:}

Invader/Invasive Species - A plant or animal that is not native and causes harm, including disrupting natural ecosystems.

Non-native species - A species introduced to a region intentionally or accidentally.

Quadrats - Survey grids of a fixed size and shape.

Point transect - A series of points surveyed along a tape measure anchored at a random point and stretched to a predetermined length. 